\title{
Decay of Ethics in David Mamet's American Buffalo
}

\author{
Ehsan Dehghani \\ Department of English Literature, Tehran Central Branch, Islamic Azad University, Tehran, Iran \\ Tel: $00989177086653 \quad$ E-mail: Mercury_lyre@yahoo.com \\ Mehdi Sepehrmanesh (Corresponding Author) \\ Department of English Literature, Karaj Branch, Islamic Azad University, Karaj, Iran \\ Tel: $00989195285469 \quad$ E-mail: mehdi.sepehr330@gmail.com
}

Received: 15-02-2013

doi:10.7575/aiac.ijalel.v.2n.5p.10
Accepted: 26-05-2013

Published: 01-09-2013

URL: http://dx.doi.org/10.7575/aiac.ijalel.v.2n.5p.10

\begin{abstract}
The American Dream is a recurrent theme in American literature. In this response, this paper is an attempt to expose the destructive effects of the dream on human spirits and relations and how it is contradicted in different ways through the analysis of his brilliant play, American Buffalo by David Mamet. Beneath the seeming simple surface of the play lies a deep current of meanings that reflect the calamities of modern American life, and in a broader sense, the modern world. This article indicates how capitalism inculcates ideologies in the mind of individuals in order to facilitate the exploiting process and unquestioning subordination. Ragged individualism, as one of these ideologies, disrupts all communal bonds and even exceeds to the disintegration of friendship and family life. On the other hand, this individualism, as an ideology, is sustained by other capitalist ideologies such as advertising, consumerism and emulation. It will also be discussed that monetary interests are all one seeks in a highly competitive atmosphere and nothing is privileged over business ethics. In brief, this reading of the play tries to illuminate that we live in a dream-like world of ideologies that block logical thinking and forge our relationship with our real existence through less suspected ways.
\end{abstract}

Keywords: American Dream, Ideology, Capitalism, Individualism, Consumerism

\section{Introduction}

The objective of this article is to analyze David Mamet's American Buffalo in the light of the American Dream. Therefore, it will be demonstrated that what are the dehumanizing effects of the dream, how its principles are contradicted in the face of reality and what befalls those who take the dream too seriously and are deluded by it. The characters of the play are to some extent like Vladimir and Estragon who are too obsessed with the coming of Godot that they cannot see the reality of their miserable existence; likewise, they are enchanted by the American Dream to the extent that they cannot perceive have far they have diverged from reality. They are pretty similar to the tramps in Waiting for Godot (1949) in the sense that they have nothing to do with the present while fluctuating between the past and the future. In other words, the splendid dreams of the past are juxtaposed with the utopian future promised by the American Dream.

David Mamet, a screenwriter, director, essayist, poet, novelist, and most importantly an outstanding feature in contemporary American drama, was born in Chicago in 1947. He attended Goddard College in Vermont, where he graduated in literature and drama in 1969. During his junior year, he also studied acting under the direction of Sanford Meisner at New York's Neighborhood Playhouse. Having finished his studies, Mamet taught acting for a year at Vermont's Marlboro College. In 1971 with some of his students like William H. Macy and Steven Schachter, he founded the St. Nicholas Theatre Company. His experience in doing different blue-collar jobs has put him in touch with a variety of social classes which as a result has widened the horizon of his language flexibility in employing idioms and rhythms of everyday speech in his plays although it is not a blind mimicry of the street talk and has its unique features.

To talk about Mamet's style, before everything else our attention is drawn to his special use of language. His writing style has been influenced by Harold Pinter (1930-2008) whom he admires. Mamet's language after all possesses its unique quality which is often referred to as Mamet's speak. His language is marked by minimalism which is carried out through ellipsis and the omission of unnecessary parts. Therefore, as Zander Brietzeke (2007) states, Mamet's plays remain "much more elliptical and [demand] that the viewer/reader pay close attention to clues in the performance/text that will explain the situation" (p. 122). The obscenity, vulgarity, incessant pauses and interruptions of this language, which makes it the playground of monologues rather than relevant dialogues, best reflects the impurity and chaotic environment his characters inhabit. To quote Benedict Nightingale (1994): "he is the bard of modern-day barbarism, the laureate of the four-letter word" (p. 332). Apart from language, he uses narrow settings for his plays and casts few characters. Moreover, as Zander Brietzeke (2007) elaborates: "He reduces the world of the [plays] to a series of sales transactions in which the man who succeeds - and it is the man's world - is the one who can successfully close the deal and exert his will upon a victim ... How much money they make, what cars they drive, if they're married or not, where they live ... and how many kids they have remains a mystery" (pp. 125-6). As Christopher Bigsby (2004) suggests: 
"In a utopian society such as America only the past and the future offer a true form. . . . In between is a provisional world in decline, reaching for a perfection beyond immediate reach, existing between impure nostalgia and importunate hope" (p. 20). Mamet's characters inhabit a world where in Esther Harriott's words (1983): "There is a preoccupation with rootlessness - felt both as discontinuity with the past and the failure of connection with the present-and with the fear of apocalypse" (p. 9). In fact, this illusion of the glorious past and a utopian future, compared to the devastating conditions of the present time, functions as a defense mechanism, employed to avoid the confrontation of the horrifying reality of their existence. However, despite all attentions made to Mamet's works, a reading of American Buffalo in the light of the American Dream in which all individuals are deluded by the deceiving ideologies not to recognize their real existence.

\section{Methodology}

One also must be aware that there might be controversies over the concept of the American Dream. The controversies might arise from the fact that some might claim that there is no solid ground on which we can establish a clear definition of the American Dream. It is true that the meaning of the term has undergone many changes and that not only it has always had numerous definitions in different eras and contexts, but also it has been referred to differently by different groups in the same age simultaneously. However, as a recurring theme in the American literature the meaning of the term has been crystallized in the field of literary studies and thus there remains no doubt what is meant by it. One great limitation underlying studying literature in the light of American dream is that to have a better grasp of the meaning of the term, one needs to have a background of America's social, cultural, economical and historical conditions gained through extensive studying. After all, Marxist critics, more and less, see a literary work as the product of a society which breeds it. The relation of the society and the literary work is mutual and the examination of the either reveals facts about the other one.

Since this paper is devoted to the analysis of David Mamet's American Buffalo in the light of the American Dream, a glance at the background of the dream might be helpful as a starting point. In fact, the American Dream is as old as the foundation of America itself. Ironically, the foundation of America was stimulated by the dream when many people from the old world crossed the ocean in search of better life and future in the fertile west while being tired of the muffling and exhausting conditions of Europe. Thus, America with its abundant opportunities was supposed to be the Promised Land. However, in the course of its evolution, from the possession of land, freedom and gold fever to the present time greed for wealth, the dream has failed time and again, but despite these failures the dream continues to survive stronger than before. The point is that as Lois Tyson asserts (2006): "The American Dream Blinds us to the enormities of its own failure, past and present: the genocide of Native Americans, the enslavement of Africans, the virtual enslavement of indentured servants, the abuses suffered by immigrants populations, the widening economic gulf between America's rich and poor, the growing ranks of homeless and hungry, the enduring socioeconomic barriers against women and people of color, and the like" (p. 58).

To be more precise, we must bear in mind that the American Dream is an ideology that blinds us to the realities of our life and that it is on us to be more vigilant to the mesmerizing ideology and less vulnerable to its propaganda. Although it might be objected that total freedom from the enthrallment of ideologies is out of the question, at least there is still a ray of hope that through thinking we would not remain lifeless individuals in the society we live. In addition, it must be noted that giving up thoroughly to the capitalistic ideologies might lead, in a broader sense, to imperialism. Here, in order to put more emphasis on the significance of this issue we rely on Charles D. Hayes's (1998) statement that: "Reality suggests that today's American Dream has become the residue of media technology, that millions of us tune in for instructions on what to buy, wear, think about, and value — even what we should dream. Indeed, for now, we must take time to examine some current realities before we delve further into dreams" (p. 17).

The very infrastructure of the American Dream is based on consumerism, advertising and emulation. These are, themselves, the result of individualism nourished by the capitalist system. Furthermore, capitalism declares that competition is the best way towards success, yet it is not something progressive but destructive since not everyone is given equal chance and the success of one means the failure of the rest. Therefore, in a society where competition, in its negative sense, is promoted as a value, it comes to follow the Darwinian rule of the survival of the fittest that implies one's survival depends only on the annihilation of the others. The American Dream commands that everyone has equal opportunity to get successful, but the truth is that once one volunteers to pursue the dream one enrolls in an endless competition that merely exhaust the competitors but fills the coffers of the bourgeoisie who conduct the process invisibly. Thus, as Lois Tyson (2006) expresses; "the American Dream is certainly good for capitalistic economics, but it sacrifices the well-being of the many individuals who don't achieve it" (p. 65).

Ragged individualism in addition to creating a climate of destructive competition, that means hit or die, promotes consumerism as a noble culture. In competition with one another to survive, every single member of the society is encouraged to have upper hand over his or her rivals through buying and consuming more and more of goods. In this sense, those who possess more goods are considered the privileged class; as a result, human beings are evaluated by what they possess and not by their moral traits. Since in the capitalistic society human beings and morality are commodified, no space is left for sympathy for humanity. In other words, commodification of moral values legitimates the victimization of others. The salesmen of the Mamet's plays, for instance, are human beings who are crushed under the frenetic drives of the American society which forces them to consume themselves and others to reach the top. They suck the blood of their naïve customers and each other alike. The irony is that, while they ruthlessly victimize others they are themselves victimized by the same system of which they are a part. 
Although individualism might seem to be total independence experienced by the individuals to move in every direction they aspire, the evidences proves that enslavement under the guise of individualism governs and regulates the actions of the individuals. This so-called individualism is, in fact, controlled through different means such as "Ideological State Apparatus" of which the American Dream, as we have seen, is an example. So, Tyson (2006) considers: Rugged individualism [as] an oppressive ideology because it puts self-interest above the needs - and even above the survivalof other people ... Rugged individualism also gives us the illusion that we make our own decisions without being significantly influenced by ideology of any sort when, in fact, we're all influenced by various ideologies all the time (p. 60 ). On the other hand, the individuals are allowed to act freely as long as they are subservient to the oppressive power that programs them. Consequently, as soon as they cross the line to turn against the system under which they operate , the alarm rings warning those in power that ideological tools have lost their efficiency; therefore, physical force have to be employed to extinguish the uprising. To put it another way, what is referred to as "Repressive State Apparatus" steps forward to restore the slavery of the subjects. In this respect, signs of this overwhelming force can be traced in American Buffalo.

\section{Business Versus Friendship}

The plot of American Buffalo revolves around a robbery that is expected to be carried out by the main characters of the play that together form a trio. Don Dubrow is the owner of a junkshop who believes that he has been duped by a customer who purchased a buffalo-head nickel from him for much less than its real worth. The customer bought the coin for ninety dollars but Don definitely claims that "I bet it's worth five times that" (American Buffalo, p. 31) and complains that he has been robbed when he tells Teach, his associate: "He takes me off my coin" (Ibid. 31). Therefore, Don plans to steal back the coin and assigns Bob, his gopher, to spy on the coin purchaser so that they can break into his apartment in his absence. However, when Teach, Don's associate, finds out about the scheme, he tries to persuade Don to rule out Bob from the plan and replace him instead. However, after many arguments between characters, the heist is ultimately left untried and never carried out.

Throughout the play both Teach and Bob compete with each other to attract Don's attention and friendship. However, all the characters in the play are torn between friendship and business inclinations which are at odds with each other. They suffer under this harsh conflict since to incline to either pole means to keep aloof from another pole. The business tendencies are so vigorous because as Douglas Bruster (2004) clearly states, "Mamet's characters are bent more on sheer survival. Significantly, much of the playwright's ideology seems to assume the principle of natural selection" ( $p$. 50-1). However, they feel deep inside the need for friendship and emotional bond. David Mamet (2004) declares that American Buffalo is a tragedy which concerns the disintegration of family life under the materialistic system. He elaborates:

American Buffalo is a classical tragedy, the protagonist of which is the junk store owner who is trying to teach a lesson in how to behave like the excellent man to his young ward. And he is tempted by the devil into betraying all his principles. Once he does that, he is incapable of even differentiating between simple lessons of fact and betrays himself into allowing Teach to beat up this young fellow whom he loves. He then undergoes, as I have said, recognition in reversal - realizing that all this comes out of his vanity, that because he abdicated a moral position for one moment in favor of some momentary gain, he has let anarchy into his life and has come close to killing the thing he loves. And he realizes at the end of the play that he has made a huge mistake, that, rather than his young ward needing lessons in being an excellent man, it is he himself who needs those lessons. That is what American Buffalo is all about. (qtd. in Matthew Roudane, p. 66)

Definitely American Buffalo is a tragedy that laments the disintegration of all communal bonds. The playwright specially tries to bring into focus the family as the smallest unit of society and exposes the destructive forces that threaten human relationships. The play implies that the suppression of morality in favor of self-interest makes society a chaotic environment where love and sympathy have no place.

In the course of the play we see Teach as the feverish adherent of the American myth. He constantly, as a mentor, preaches about free enterprise and is prone to discard moral codes in favor of business. He is obsessed with business and talks in a way as if he is a successful businessman while in fact evidence shows that he has never accomplished in business world. We first see Teach enter the junkshop in anger while he curses Ruthie. He tells Don how he has been humiliated by two female friends, Grace and Ruthie, when he sits at their table at a coffee shop and Grace sarcastically tells him "Help yourself" when he tries to "take a piece of toast off Grace's plate" (American Buffalo,p. 10). The underlying meaning of this scene may subtly allude to the ruthless capitalism in which the poor starve to death while the rich gormandize. It depicts a world where, as Claudia Durst Johnson (2006) declares, "the leftover food from [the] banquet" of the rich is "dumped for the poor to consume" (p. 41).

In his constant fear of not being accepted to participate in the heist, that is convincingly taken as doing business, Teach charges everyone with dishonesty and tries to convince Don that it is only he who is trustworthy and fits the scheme. He judges that no one is trustable and concludes that Ruthie cheats at cards, Fletcher stole the pig iron from Ruthie and also cheats at cards, and Bob is a junkie who might miss up the whole plan and is also suspect of being an accomplice to Fletcher. Teach is all the time anxious to win Don's trust and friendship. It is interesting to note that while Teach urges Don to trust him and puts emphasis on the importance of friendship, it is he who destroys all bonds of friendship between the characters of the play. The anxiety that Don may choose Bob for the plan and the preference of Bob over 
Teach, never leaves Teach alone. Teach considers Bob as a rival for his friendship with Don and tries to knock him down by bringing up his drug habit and dumbness all the time. In fact, as long as Don cares about Bob, he is an obstacle to Teach's friendship with Don and despite the fact that Don resists Teach's temptation to neglect Bob, he ultimately gives up and agrees to substitute Teach for Bob. However, Teach is aggressive towards Bob since he is still a threat to him and Don is still affectionate to Bob and at times even suspects if it is right to put him aside.

Teach is obsessed with business world, but he also carves Don's friendship and affection. At times he succeeds in having influence on Don and; therefore, proving his authority on him as well as his magical power to manipulate. However, the positive tendencies of morality plus the need for communication with the human fellow contradict with the dictates of the capitalist world. This tears Teach between being either a true friend or an unsympathetic businessman. He knows well that to express love and sympathy for friends is a weak point in the cold world of business and may lead to failure. As a result, he sees the world through the lens of business ethics. From business perspective, Teach sees friends as mere competitors that have to be defeated and kept down if one is to have any chance to survive. He believes that the more he discredits friends, the more he gains credit as a true friend which also invests him with probable benefits. This clearly justifies why he looks at Bob as a rival to himself that must be defeated.

Teach fantasizes himself as a successful businessman who knows how to go through business and win in the end. He lives in a hallucinatory world and all the time fabricates stories to make it seem more real. He talks, for instance, about the robbery as if it is real business and he knows how to deal with it, but he is perplexed when Don simply asks him how to break into the coin collector's apartment and what if the man has a safe, which in response Teach stubbornly insists that he will find a way while he refrains from explaining how. In this regard David Krasner (2006) explains that "Teach is angered by the skepticism directed his way. Yet for all his machismo, there is humor in the fact that he is not better prepared for breaking and entering than Bobby. His breaking the window or kicking in a back door hardly qualifies as superior know-how. Not action but Teach's language persuades Donny" (p. 104). Teach justifies his actions as business and sees nothing wrong with the robbery. As he gets prepared to carry out the robbery, he intends to carry a revolver as a precaution against "some crazed lunatic" and when he is objected by Don, he justifies that "all the preparation in the world does not mean shit, the path of some crazed lunatic sees you as an invasion of his personal domain. Guys go nuts, Don, you know this. Public officials, Ax murderers all I'm saying, look out for your own" (Buffalo, p. 85). He tries to identify himself as a wise man who must be precautious before taking any action. However, it is ridiculous to note that he has a subverted understanding of reality and conceives the owner of the apartment as an intruder who is to hurt him, while in fact it is he who is to break into his privacy. Teach even identifies himself with cops as he sees them pass the corner and admires them: "They have the right idea. Armed to the hilt. Sticks, Mace, knives. Who knows what the fuck they got. They have the right idea. Social customs break down, next thing everybody's lying in the gutter" (Ibid. 86). It is as if he is to punish some law breaker while he fails to see himself as the one who is to break the law. Teach's behavior is paradoxical since he considers himself as the victim of brutality and dishonesty, and accuses all as opportunists while he is to violate moral codes and participate in crime.

In Act two, as Teach is about to leave to carry out the robbery, Bob reappears and informs them that Fletcher, an accomplice who has been arranged previously to assist Don in the robbery, has been mugged and is in the hospital, but Teach is suspicious of the news and believes that Bob is to outsmart them and wants to join Fletcher to steal the coin collection together. Teach is certain that Bob lies to them and tries to persuade Don that Bob is a conspirator while he starts interrogating him about the name of the hospital Fletcher has been taken to, and Bob in confusion utters a name that proves to be wrong as Don calls the hospital named by Bob and asks for Fletcher. It is the climax of the moment that Don's trust in Bob is shaken and he gives up to Teach's temptation that Bob is a fraud. The growing distrust which shakes the pillar of friendship between Don and Bob is exactly marked by the physical violence when Teach grabs a nearby object and viciously hits Bob on the head. This physical violence is in harmony with Don's feelings of mistrust and the disintegration of friendship which leaves Bob unprotected and allows him to be hit by Teach. Some moments later, Ruthie calls and informs Don that Fletcher has been mugged and is already in the hospital. Teach trashes the junkshop in anger when he finds out the truth since his fabricated world, which he has taken for granted, is shattered once more. Moreover, all his affords to discredit Bob finally leads to his own disrepute and again he has to restore his place as a friend to Don and a member of the small family. As Bob gets hit, he admits that he has made a mistake and confesses to Don that he has lied about seeing the coin purchaser leaving his apartment and that he has not been actually spying on the man. In the meantime, Don calls off the robbery as he finds about the truth and comes to realize that he has let himself to be manipulated by Teach and business ethics.

Business ethics makes Teach conceive both the robbery and friendship as business deals. However, he succeeds in neither being a successful business man, as the robbery fails, nor a true friend, as he fails to win Don's attention and have any influence on him. In fact, Teach's anger mainly stems from this impotency. Furthermore, he considers himself to be the victim of dishonesty and betrayal while he himself is not obliged to any moral principle. Teach becomes so frustrated when he finds out that he is neither able to secure his place in friendship nor in the business world. Therefore, he sees himself as the victim of the brutal environment that obstructs his survival. His obscurity in the harsh world is implicitly indicated in the play as he does not even own a place to dwell on and has to stay at a hotel. In addition, although he claims that he has broken his watch, one might suggest that he has pawned the watch to borrow the gun. This may allude to the fact that he has sold his property to buy protection in a world that he feels to be threatening. In his competition with Bob to win Don's friendship, it is he who eventually fails. Teach regards himself the victim of dishonesty and believes that his sacrifice for the sake of friendship has been rewarded by betrayal when he complains to Don: "I went on a limb for you. You don't know what I go through. I put my dick on the chopping block. I hock my 
fucking watch. I go out there. I'm out there every day. There's nothing out there. I fuck myself' (American buffalo, pp. 103-4). As the play comes near the end, Teach successively asks Don as if he is mad at him and in helplessness pleas for Don's forgiveness although he stills fears to expose his feelings explicitly since the exposure of what one really feels might make one vulnerable to others. Matthew Roudane (2004) explains that "this a play that begins with men assuring themselves that they are not 'mad' at each other and ends with men voicing similar assurances. The fragility of friendship acknowledged, however awkwardly and without full comprehension of the reasons for such awareness, Teach, Don, and Bob reconnect with each other" (p. 71). We see Teach exits the junkshop with a paper hat while it is raining outside. The paper hat at end of the play may symbolically allude to the fragility of friendship. This means that as the paper hat can not resist the drops of the rain and gets drenched and is deformed by water, so their friendship is influenced by the materialist world and is contaminated by the corrupted ethics of business.

The play begins with Bob apologizing Don for the failure in some sort of business which he has been assigned for. Don sermons Bob on business and mentions that one has to take business serious if one is to succeed. Don emphasizes business priority over any other concern and even distinguishes between friendship and business when he explains to Bob that "there's business and there's friendship" (American Buffalo, p. 7). In fact, what he tries to get at is that business is much more significant than friendship. It is also Don's conviction in the priority of business over any other concern that paves the way for the failure of friendship and the consequent betrayal. This conviction dictates that if one is to conduct business and get successful, one must discard all moral obligations including friendship. Don is the owner of the junkshop and advises Bob on the business ethics as if he is a self-made businessman who precisely knows how it works. However, his sale of the buffalo-head nickel to a stranger proves the opposite. He does not have a true sense of what might be the true value of the coin and even hardly knows about its existence in his junkshop. In fact, the coin is a discarded object in the junkshop, but as soon as someone agrees to pay ninety dollars for it, it becomes quite valuable and Don conceives that he has been cheated. It is also meaningful to say that Don believes that his reputation as an experienced businessman is now in question and he has to restore his reputation by stealing back the coin from the purchaser. He is obsessed to prove that no one can cheat on a businessman through repossessing the coin. Consequently, he takes the robbery as a business enterprise since any wrongdoing is legitimized by business ethics. Moreover, as June Schulueter and Elizabeth Forsyth (1994) represent, "the junkshop, with its piles of once treasured, now rejected cultural artifacts, proves to be a powerful image for an America in which the business ethic has so infiltrated the national consciousness and language that the traditional human values have become buried under current values of power and greed" (p. 322). In fact, the junkshop itself, which is piled up with consumed objects, is the representative of the corrupt business world and consumed morality.

The relationship between Don and Bob is like that of a mentor and an apprentice. Don has the authority to advise and assign Bob with tasks. On the other hand, Bob, as an apprentice, also acknowledges his subordination to Don's authority and frequently asks for forgiveness whenever he feels Don is mad at him.

However, Don's lack of knowledge of the real value of the coin clearly illustrates that he is neither a well-to-do shop owner nor an expert who can give advice on business and at times we even feel as if he is more stimulated by taking revenge rather than finding out the real value of the coin. By taking the role of a mentor whose words are regarded authentic, Don establishes his power and superiority which compensates for his business impotency. Don and Bob together constitute a kind of relationship in which Don is a superior and Bob willingly acknowledges his role as a student who needs Don's guidance. By instructing Bob, Don validates himself as an advisor who has knowledge and experience. In fact, the more he sermons Bob on life and business ethics, the more he gains authority. However, despite all his sermons, Don gives up to Teach's temptations and as he listens to him, he implicitly hands over his mentorship to Teach and becomes a student himself. Throughout the play both Don and Teach gain the power to instruct on different occasions and consequently control the conscience of the trio. As David Radavich (2004) elaborates: "The illusion to education [is] embodied ... in both Teach and Don, who continually moralize, philosophize, and pontificate about the nature of life, people, and business. The "knowledge" actually taught, however, is both corrupt and clumsy, so that by the end, the traditional mentoring of males in the world of business has collapsed into mutual incompetence" (p. 72). It is also very helpful to note that the application of the name Teach for a character who is obsessed with manipulation and distortion of reality is quite ironical.

Along with his educational authority, Don also compels himself to look after Bob. He, in fact, burdens himself with a paternal responsibility towards Bob. Don is even concerns about Bob's well-being, when Bob is reluctant to eat and only drinks coffee. He advises Bob on the consequences of poor nutrition: "You know how much nutritive benefits they've got in coffee? Zero. Not one thing. The stuff eats you up. You can't live on coffee, Bobby. (And I've told you this before.) You cannot live on cigarettes. You may feel good, you may feel fine, but something getting overworked, and you are going to pay for it" (American Buffalo, p. 8). In fact, many food references in the play are very metaphorical and lead one to think of Bob's refusal to eat reminiscent of Bartleby's lack of eating habit. It is to say that the refusal to eat is common to both Bob and Bartleby and the only difference is the kind of the food they consume (Bartleby lives on ginger nut cakes and Bob lives on coffee). Their refusal to eat may be interpreted as an objection to the materialistic world in which everyone is enthralled by greed and avarice, or that the materialistic world is impotent to feed the human soul. This immoral world, in Milton R. Stern's (2008) words, "neither offers nourishment nor hope for everything within us that is buttoned up beneath the surfaces of conventional acquiesces to forms and values" and ;therefore, does not provide us with "spiritual extension" of life (p. 27). 
Don is extremely obsessed with stealing the coin that he privileges the heist, as a business deal, over friendship and gives up to Teach's temptation that Bob is unfit for the robbery. Teach constantly warns Don not to mix up friendship with business and urges him to remove Bob from the plan. Don's trust in Bob begins to fade away as Teach persuades him that Bob may block off his triumph and Don sees Bob as a threat to his business carrier. Thus, as money and business considerations overcome Don's sympathy for Bob, his avarice allows him to betray Bob. In other words, as soon as Don indulges himself in the corrupt business ethics, he is prone to ignore his friendship with Bob as something worthless that not only is not enhanced by exchange-value, but also may even be a threat to his business carrier. In fact, by discarding all moral obligations, Don convinces himself to be behaving like a real businessman. He succumbs to Teach's manipulation that everyone around him is cheater and liar and takes Teach's unverified words for guaranteed. His suspicion of Bob's betrayal is exacerbated when Bob reappears with another buffalo-head nickel. Therefore, Bob's return to the junkshop with an identical coin near midnight, his breaking news of Fletcher being in hospital because he has been mugged, as well as his mistake to name the right hospital, all leave Don no doubt that he has been duped by Bob. As a result, in reaction to Bob's betrayal, Don allows him to be mistreated emotionally and physically by Teach. However, as Edward J. Esche (2004) nicely expresses: "Our judgment at the point immediately before Teach's attack on Bob is clouded by the choices forced on us by Mamet, or rather the choice of judgment that Mamet leads us into making, which is that Bob has transgressed. The moment of enlightenment, of reversal, of recognition that we are wrong begins at the moment that the 'object' cracks Bob's skull" (p. 87). Therefore, although one might be deceived, at some points, to think that Bob is suspect of betrayal, he is the most innocent character of the play, whose actions are not motivated by self-interest, but are out of love for friendship.

As truth is unveiled and Don finds out that Bob is innocent and all his actions have been out of love for him, he feels guilty and insists that they must take Bob to hospital immediately. Don realizes that Bob has been loyal to him and is a true friend while Teach can not be trusted as a friend. He also understands that the business world is replete with corruption and hypocrisy that threatens their friendship. He discerns that he himself has not been without mistakes and his obsession with business enterprise prevented him from exercising humanistic behavior and made him egoist. Therefore, the fragility of friendship is illustrated as the three characters realize their mistakes. According to C. W. E. Bigsby (2004):

Beyond a social critique of American business values, American Buffalo is a play about failed relationships, about the gap between people whose need for contact is as real as their evasion of it. There is a real affection between Don and Bobby, albeit one betrayed when it conflicts with business. Teach has as great a need to be 'well liked' as had Willy Loman, except that he can never permit anyone access to his inner life or acknowledge the genuine sense of vulnerability which he feels. Bobby, too, desperately craves affection. Not the least of the ironies of the play, however, is that need can never align itself with action. The characters never quite allow themselves the openness necessary for genuine contact. Something has destroyed their sense of being part of a community of selves. If this is in effect a kind of family then it is as broken as are the families in Reunion. (p. 179)

The trio, in fact, together shape a family and Don's position as the head of the family is restored as both Teach and Bob ask for his forgiveness. As order is restored in Don's trashed junkshop, so peace and friendship is restored between the members of this small family. In fact, the junkshop is pretty much like a house where the family members stay together and calm down. It is the only place they can refuge against the harshness of outside world. In this regard, David Krasner (2006) represents that:

In American Buffalo, the junk shop setting serves as a safe haven for the three characters. The play explores the male bonding of small-time hoodlum who huddle together for protection. Inside (onstage) there is safety; outside (offstage), danger. Inveterate losers, they form an extended family. Their ineptitude - their scheme to steal a buffalo nickel goes awry - is likely one of several missed opportunities. They symbolize the dog-eat dog system that is the basis of American business. Here is where business loyalty shifts precariously depending on who "holds the cards." (pp. 103-4)

Consequently, the family members vaguely discern that while the corrupt business disrupts community and sympathy between them and has terrible effects on their relations, true friendship reinforces their community and protects them against the harsh world.

As explained previously, there exists a pedagogical relationship between Don and Bob in which Don is the master and Bob is his student. Bob whole-heartedly listens to Don's lectures on different subjects. As an eager student, he tries his best to precisely behave according to what he is taught. Bob is a student who looks at Don as a paradigm that must be followed unquestioningly and apologizes to him at times for failing to accomplish his task as a student. Don, for instance, advises Bob that this is not the way business works when he fails his mission to watch for the man who bought the coin from Don. We also see that although Bob admits Don's statement that Fletcher is skilled at playing cards, he seems to be the only character that is not afflicted by corrupt business ethics and ultimately proposes that Fletcher stole the pig iron from Ruthie. As the events unwind in the course of the play, it is revealed that Bob has lied about seeing the coin purchaser leaving his apartment with a suitcase and that he has not been spying on him at all. Nevertheless, Bob is still the most innocent character in the play since he desperately extends the lie throughout the 
play out of need for Don's attention. Therefore, as Edward J. Esche (2004) suggests, "one might say that he confusedly tried to be part of a mini-society, which revolves around Don's shop, into which he was incapable of fitting. He was simply in pursuit of that which we all 'desire most, which is love and a sense of belonging"' (pp. 87-8). Bob not only does his best to put into practice whatever Don tells him, but is also determined to assist Don to steal back the coin in order to retain his friend's violated reputation. Unlike other characters, Bob does not behave self-interestedly, but as Edward J. Esche (2004) illuminates: "Quite the contrary, he has tried to do what he thinks is right throughout the play, and his actions have always been motivated by a friendliness to others, not by an obsession with himself. Examples of this include his asking Ruthie if she is mad at Teach, of buying a new buffalo-head nickel for Don, and even of lying to Don about the man leaving his apartment" (p. 88). Bob's acquisition of another buffalo-head nickel, which he offers to Don, is a sign of his concern for Don rather than betrayal. He simply means to return to Don what he has lost. In fact, Don regards the coin as an object with exchange-value that may make him profit, while for Bob the coin is quite worthless and is merely used as a means to reinforce his friendship with Don. Therefore, the irony is that it is Don, rather than Bob, who needs lessons and although he boasts of friendship theoretically, it is Bob who ultimately proves it in practice. Moreover, the application of the buffalo-head nickel itself, as the central motif of the play, is quite symbolic and may be interpreted in many different ways. It may refer to the American Dream, meaning that as the buffalo has been slaughtered and only its memory continues to exist dimly, so the American Dream has become corrupted and is hollow within despite its flamboyant promise. It also may allude to the fact that as the Buffalo has become extinct and solely resurrects on a piece of metal, so friendship has faded away and is rare to be found. Furthermore, the coin, as the symbol of money, may suggest that all moral traits such a friendship and dignity are associated with money and that actually all human interactions revolve around it.

\section{Material Versus Representation}

David Mamet is a playwright who is obsessed with the way the modern life has caused the detachment between the reality of entities and what they falsely represent. He specially manifests this anxiety in American Buffalo over the issue of money since it has destroyed the relation between the reality of objects and their representation. As explained in previous chapter, money, as a means turned into the end, is an abstract entity which gives meaning to concrete objects and therefore blurs the borderline between reality and representation; abstract and concrete. Georg Simmel (2004) in The Philosophy of Money recognizes that as soon as money, as the absolute means, is turned into the absolute end, it reduces all entities to absolute means and makes their value relative to money. Thus, while the increasing relativity of the value of objects makes them dependent on money to define their worth, money remains as an independent value that does not subordinate to this relativism which it establishes. Simmel elaborates that as norms and rules set up obligations, money regulates relationships between objects and all aspects of life, yet it exempts itself to act within the framework of these regulations. In this respect, he states that:

Norms are the types and forms of relativity that develop among, and give form to, the specific phenomena of reality.... These norms are not relative in the same sense as the objects subjected to them, because they themselves present the relativity of the objects. Thus it becomes comprehensible that money as abstract value expresses nothing but the relativity of things that constitute value; and, at the same time, that money, as the stable pole, contrasts with the eternal movements, fluctuations and equations of the objects. (p. 119)

Moreover, this alludes to the fact that although money is materially void of value, it defines all values. Therefore, the more money gains independence as a result of having authority to set value on all values while it exempts itself from the existing relative connections between objects, the more objects subordinate to money and; therefore, lose their independence. In the past, objects used to retain their individuality, but by the introduction of money they lost this individuality and there remains no object that is not exchangeable for money. Thus, as Simmel (2004) explains: "To the extent that things are exchanged for money, they share this lack of individuality. The absence of any inherent worth in an object cannot be more distinctly expressed than by substituting for it, without any sense of inadequacy, a money equivalent. Money is not only the absolutely interchangeable object, each quantity of which can be replaced without distinction by any other; it is, so to speak, interchangeability personified" (p.122). It is true that inherent value is absent to money, but money as an intrinsically valueless object continues to regulate the transactions between inherently valuable objects. Therefore, despite the fact that the value of money is something abstract, it is the absolute value that determines over the objects which have concrete value.

As mentioned, American Buffalo is a play in which Mamet is concerned about the increasing enthrallment of life in money economy in which the more things are deprived of their true essence, the more the authenticity of money is endorsed. In such a life, based on money as the only authentic criterion, the face value of entities is taken for reality while their real value is rejected. This reversal of substantiality and representation is so influential throughout the play that even inverts the simple conventional functions of talk and action. This is the reason why in the subverted world of reality and appearance, Don is all the time aware of the destructing force of talk and tries to restrict Teach's power through controlling his talk. In other words, as money takes the control of all materials despite the fact that it is materially without any value, so talk, rather than action, controls the events and gives bearing to them. In this regard, there are occasions in the play that Don restricts Teach's talk and consequently limits his power. For instance, as Teach attempts to persuade Don to remove Bob from the robbery since he is both a junkie and dumb, Don replies "I don't want you mentioning that" (American Buffalo, p. 34). Another instance is observable in the second act when Teach is 
mad at Don's trust in Fletcher and complains that he will not show up, to which Don again replies "Just, I don't want that talk" (Ibid. 74). Once more, when near the end of play Teach suggests that Fletcher cheats at cards, Don objects that "This is nothing but poison, I don't want to hear it" (Ibid. 80).

It is justifiable to see the entire play as a battlefield between the opposing forces that either sustain the true nature of objects, or take side with their distorted representation. The tension between these opposing forces is embodied in the characters of Don, who is still loyal to the classical valuation of objects based on what they really are, and Teach, who adheres to the conviction that it is the appearance of the objects that defines their reality. Therefore, Don's quest to steal the coin, as a symbol for real money, that he has exchanged for paper money, as a symbol for fake money, can be justified as an attempt to revive the tradition in which the objects contain their value within themselves rather than being dependent on an extrinsic criteria. Thus, in Jon Dietrick (2006) words, "in [his] rejection of greenbacks" Don rejects what he sees "as unnatural and therefore inadequate currency in favor of one with intrinsic value. Unlike paper money, which [stands] for a value located elsewhere, the 'natural' money of precious metal [is seen] as containing in itself the value it [signifies] - the metal, unlike paper money, is what it represents" (p. 334). However, Don's attempt to escape from money economy fails as the robbery falls through, because as talk acts instead of action, so money, as an abstract entity, enslaves all concepts.

In fact, the fundamental difference between Don and Teach stems from the fact that while Don conceives that "things are not always what they seem to be" (American Buffalo, p. 8), Teach asserts that "things are what they are" (p. 39). In other words, Don is suspicious of the surface value and laments the disharmony between the intrinsic value of objects and what they represent; on the contrary, Teach confidently declares that reality in not concealed beyond the surface of things and is transparent enough to be observed by everyone. Therefore, as Jon Dietrick (2006) suggests, "Teach's statement that things are what they are also marks an important distinction between himself and Don. Whereas Don is troubled by the ambiguities involved in signification - whether that signification is in form of talk or money-Teach seems to view all signs as completely divorced from reality" (p. 336).

Mamet admires the natural connection between the true essence of objects and their value and despises the disjunction of this harmony. In money economy all entities, including human beings, are commodified by money and loose their originality. Throughout his works, he implicitly suggests that modern life has obscured the line between reality and appearance and things are not what they used to be. According to Dietrick (2006), "repeatedly in Mamet's work, the most deceptive character is the one who espouses just this view of perception as uncomplicated and knowledge as totally transparent" (pp. 335-6). The junkshop in American Buffalo may stand as nostalgia for the time when objects were more real and their value was connected to what they contained. It may also allude to the fact that the rusted objects, piled up in the junkshop, represent the surrender of all materials to the power of money which makes them obsolete. For instance, the pig spreader object in the junkshop, which drains the blood from a dead pig, may refer to the fact that in the same way the pig is drained of its life blood, the objects have been drained of their intrinsic value. Moreover, as we notice, the buffalo-head nickel is the only object that is sold throughout the play and its sale precedes the outset of the play. In fact, Don's attempt to restore to the junkshop the only sold item indicates his objection to the obscuring mode of life and, in Dietrick (2006) words, "expresses a wish that money and the epistemological and ontological uncertainty it carries did not exist" (pp. 335). Thus, the scarcity of transactions in the course of the play may be justified as his objection to money economy and his failure to return the coin to the junkshop is an evidence of the bitter truth that in a world that all transactions are based on money, people like Don have no place.

\section{Individualism and Free Enterprise}

The propagation of the freedom of the individual is one of the driving forces of capitalism. However, this showy ideal never exposes the negative consequences of ragged individualism that results in irresponsibility and crime among the members of society. Individualism, in its negative sense, disrupts all communal bonds and instead spreads self-interest in society. Therefore, if self-interest becomes a norm, the individuals abandon moral behavior and the suppression of more human fellows becomes one's ladder to success. In this case, individualism is assumed to be equivalent with selfinterest and is regarded as a virtue. Under such a circumstance, only those actions are legitimatized that are to the benefit of the individual regardless of having a concern for others. To refer to Hayes (1998), "to assume people in America and throughout the world can simply live their lives unfettered by anything other than free enterprise is ridiculous, and the notion that economic virtue is inherent in capitalism is a meme advertised and paid for by the people who benefit most because of it" (pp. 204-5). Thus, with reference to the great difference between the positive aspect of individualism and destructive self-interest, one must note that free enterprise is merely an excuse for the holders of capital to control the economy and consequently rule the society under the disguise of individualism.

The shady nature of the freedom of the individual that capitalism advocates is revealed from the very beginning of American Buffalo when Don advises Bob on business issues. In fact, Don's words clearly expose the contradictions between the ideas of free will and determinism. For instance, in his admiration of Fletcher's playing cards skills, Don concludes that Fletcher has "skill and talent and the balls to arrive at [his] own conclusions" (American Buffalo 4). However, it seems that Don is not certain of what he is defending when perplexedly returns to Bob for a clue by asking "I'm saying was he born that way or do you thing he had to learn it?" Then, he again alters his statement to say that "everything that I or Fletcher know was picked up on the street" and finally comes up with a contradictory conclusion by stating "that's all business is common sense, experience, and talent" (p. 6). It is to say that Don, while giving lessons to Bob on business, does not offer a clear idea of the nature of business and this creates the irony that whereas Don is so obsessed to practice business; he even fails to define it transparently. As Dietrick (2006) suggests, "here the two poles 
of what is learned (experience) and what is innate (talent) are combined with common sense- that dubious mantra of business rhetoric that somehow denotes something both innate and learned" (p. 332). As a result, the paradox still remains that it is either skill and experience gained through practice and spending of time, or talent, as something inherent, that counts as the more influential factor in one's success.

American Buffalo is a play which indicates how individualism has declined into crime and reveals the ways that the corrupt business ethics affects the human relations. It shows how excessive obsession with making profit in the name of free enterprise has ruined the individual's sense of responsibility and moral duty and has turned individualism against the betterment of society. In this sense, in their struggle for survival, the individuals find their personal interests at odds with that of the public. As noticed in the play, practicing business is all that permeates the life of the characters and every illegal action is justified as business transaction. In fact, individualism promotes the idea that one can succeed at the cost of others and this leads to the justification of crime as a natural way of competition. Therefore, the references to crime and violence throughout the play suggest that individualism in the capitalist world endorses the Darwinian theory of the survival of the fittest which recommends that one must either kill or die. To clarify it, Teach's conviction that one must fight for survival, his devotion to the American Dream's ideal that the avenue towards success is open to everybody and that business practices are free from any obligations including moral duty, are clearly indicated in his frequently quoted definition of free enterprise:

Teach: You know what is free enterprise?

Don: No, What?

Teach: The freedom

Don: yeah?

Teach: Of the Individual . . .

Don: ... yeah?

Teach: To Embark on Any Fucking Course that he sees fit.

Don: Uh-huh

Teach: In order to secure his honest chance to make a profit. Am I so out of line on this?

Don: No.

Teach: Does this make me a Commie?

Don: No.

Teach: The country's founded on this, Don. You know this.

Don: Yeah.

Teach: Without this we're just savage shitheads in the wilderness.

Don: Yeah.

Teach: Sitting around some vicious campfire. (American Buffalo, p. 72-3)

It is exactly Teach's devotion to the ideal of free enterprise that gives him the license to equate the robbery with business transaction. To quote Roudane (2004), "in Teach's Macbethean world, where 'fair is foul and foul is fair"', crime is justified as an honorable act of business (p. 61). In fact, the corruptive effects of ragged individualism removes the difference between the notions of right and wrong and transforms the freedom of the individual into self-interest and consequently crime. As a result, the plan for the robbery ensues from Don and Teach's conviction that it is their inevitable right, as free individuals, to carry out business through every possible way they see best.

\section{Conclusion}

The American Dream is an ideology among the infinite ideologies that dominate our everyday life. This ideology is an example of a well-constructed ideology since it has survived since the foundation of America and has not withered with the passage of time. It aims at the weak point of the human nature that is a dream of better life. This is to say that, having a dream has never been apart from the nature of human kind and this dream is not indecent as long as it does not pursue exploitive ends that shut up the doors of reality and make the progressive movement towards being better human beings go awry. It means that not all dreams are to be rejected since as the history shows us there have been many dreams, once seemed to be impossible, that have come true. The dreams to fly and travel to the moon are the instances of the dreams that finally came true although they seemed quite improbable to people of earlier centuries. Thus, our focus is on the dreams/ideologies which are invented to exert power from the part of the ruling class. These ideologies tend to offer themselves as reality and it is on us to learn that there exists nothing as absolute to cling to and that every ideology is susceptible to doubt. Moreover, total subordination to the ideologies that impose themselves on us kills the spirit of creativity, hinders logical thinking and thereby leads to prejudice. 


\section{References}

Bigsby, C. (2004). "David Mamet." The Cambridge Companion to David Mamet. Ed. Christopher Bigsby. New York: Cambridge University Press.

---. “David Mamet: All True Stories”. (2004). Bloom's Modern Critical Views: David Mamet. Ed. Harold Bloom. Philadelphia: Chelsea House Publisher.

Brietzeke, Z. (2007). American Drama in the Age of Film. Tuscaloosa: The University of Alabama Press.

Bruster, Douglas. (2004). "David Mamet and Ben Johnson: City Comedy Past and Present”. Bloom 's Modern Critical Views: David Mamet. Ed. Harold Bloom.

Dietrick, J. (2006). "Real Classic Money: Naturalism and Mamet's American Buffalo". Twentieth Century Literature 52. 3 March 2010 http://www.jstore.org/stable/20479775

Esche, E. J. (2004). “David Mamet”. Bloom's Modern Critical Views: David Mamet. Ed. Harold Bloom.

Harriott, E. (1983). "Images of America: Four Contemporary Playwrights (Wilson, Shepard, Mamet, Fuller).” Diss. State University of New York at Buffalo.

Hayes, C. D. (1998). Beyond the American Dream: Lifelong Learning and the Search for Meaning in a Postmodern World. Wasilla, AK: Autodidactic Press.

Krasner, D. (2006). American Drama 1945-2000: An Introduction. MA, USA: Blackwell Publishing.

Johnson, C. D. (2006). Labor and Workplace Issues in Literature. Westport: Greenwood Press.

Mamet, D. (1996). American Buffalo. Ed. Gregory Mosher. New York: Grove.

Nightingale, B. (1994). “Is Mamet the Bard of Modern Immorality?” Drama Criticism. Eds. Laurence J. Trudeau, et al. Vol. 4. Detroit: Gale.

Radavich, D. (2004). “Men among men: David Mamet's Homosocial Order”. Bloom's Modern Critical Views: David Mamet. Ed. Harold Bloom.

Roudane, M. (2004). "Betrayal and Friendship: David Mamet's American Buffalo". The Cambridge Companion to David Mamet. Ed. Christopher Bigsby. Cambridge: Cambridge University Press.

---. (1994). "Public Issues, Private Tensions: David Mamet's Glengarry Glen Ross.” Drama Criticism. Eds. Laurence J. Trudeau, et al. Vol. 4. Detroit: Gale.

Schlueter, J., \& Elizabeth F. (1994). "America as Junkshop: The Business Ethic in David Mamet's American Buffalo". Drama Criticism. Eds. Laurence J. Trudeau, et al. Vol. 4. Detroit: Gale.

Simmel, G. (2004). The Philosophy of Money. Ed. David Frisby. $3^{\text {rd }}$ ed. Trans. Tom Bottomore and David Frisby. London: Routledge.

Stern, M. R. (2008). "Towards Bartleby the Scrivener". Bloom's Modern Critical Views: Herman Melville. Ed. Harold Bloom. New York: Infobase Publishing.

Tyson, L. (2006). Critical Theory Today: A User-Friendly Guide. $2^{\text {nd }}$ ed. New York: Routledge.

---. (1994). Psychological Politics of the American Dream: The Commodification of Subjectivity in Twentieth-Century American Literature. Columbus: Ohio State University Press. 